\title{
Acknowledgments
}

My deepest appreciation goes to all of the individuals who helped make Students Together the welcoming, empowering, and transformative program that it was for so many young people over the years. From the visionary and founder, to the staff members, Americorps volunteers, undergraduate and graduate students, curriculum designers, and those in administrative roles behind the scenes, you have made a lasting impact. I would also like to thank the young people who worked through this program and beyond to make their communities and the world a more just and compassionate place. I owe a particular debt of gratitude to the students who gave their time over and over again being interviewed for this project. This book would not exist without you. You have been so generous, tenacious, and inspiring.

I am fortunate to have worked with outstanding faculty members who saw me through the beginnings of this book at Stanford University. I am especially grateful to my advisor Michael Rosenfeld for being a tireless sounding board and sage mentor, and for providing practical advice and genuine encouragement. I am also grateful to Milbrey McLaughlin for taking me under her wing and always expecting the best and to Monica McDermott for her guidance, intellect, and unending kindness.

In addition, I have had wonderfully supportive colleagues and mentors. I am thankful for Professors Susan Silbey and Barbara Beatty at Wellesley College for first inspiring my sociological imagination. Anahi Aguilar, 
Maria Fernandez, Jon Norman, Mary Hofstedt, and Sarah Miles deserve special mention for their critical contributions to research design and data analysis. Craig McEwen and Karen Strobel have been patient mentors and irreplaceable and ongoing supports. I am grateful to Stanford University and the Robert Bowne Foundation for the financial assistance that made this research possible, and to Bowdoin College for the research leave that allowed me to complete this book. I would like to thank my editor at Rutgers University Press, Peter Mickulas, for his support and for working so efficiently to see this manuscript through to publication. Richard Lerner and an anonymous reviewer generously read and provided feedback on a draft of this manuscript. I also want to express my gratitude to a community of scholars and friends that have made the writing process more bearable: Shaun Golding, Natalie Privett Yu, Erin Schenck, and Kelly Tuomokoski. And, of course, I owe many thanks to countless others who have supported this project and my development as a scholar in so many ways.

Finally, I am grateful to my immediate and extended family, for all that they are and all that they do. I have been beyond fortunate to grow up with the love and encouragement of amazing grandparents, aunties, uncles, siblings and cousins. My parents have been my biggest cheerleaders since the beginning. My wife, Allyson, has been there for me in the good and the bad, every single day. Words cannot express my gratitude for her love, support, and humor. Lastly, I am grateful to Miles for his unending spirit and love of books, and to Lydia for being the best kind of deadline. 


\section{Why Afterschool Matters}


